University for Business and Technology in Kosovo

UBT Knowledge Center

UBT International Conference

2017 UBT International Conference

Oct 27th, 3:00 PM - 4:30 PM

\title{
Educational buildings in Albania: Typologies based on morphological developmen
}

\author{
Ledita Mezini \\ Polytechnic University of Tirana, ledita_mezini@yahoo.com \\ Ani Tola \\ Polytechnic University of Tirana, apanariti@hotmail.com
}

Follow this and additional works at: https://knowledgecenter.ubt-uni.net/conference

Part of the Architecture Commons

\section{Recommended Citation}

Mezini, Ledita and Tola, Ani, "Educational buildings in Albania: Typologies based on morphological developmen" (2017). UBT International Conference. 12.

https://knowledgecenter.ubt-uni.net/conference/2017/all-events/12

This Event is brought to you for free and open access by the Publication and Journals at UBT Knowledge Center. It has been accepted for inclusion in UBT International Conference by an authorized administrator of UBT Knowledge Center. For more information, please contact knowledge.center@ubt-uni.net. 


\title{
Educational buildings in Albania: Typologies based on morphological development.
}

\author{
Ledita Mezini, Ani Tola \\ Faculty of Architecture and Urbanism, Polytechnic University of Tirana, Tirana, \\ Albania, \\ ledita_mezini@yahoo.com,apanariti@hotmail.com
}

\begin{abstract}
There are about 3400 school buildings in Albania and constantly new schools are being renovated and built. It is widely known that the educational sector and the built environment contributes to the achievements of learning and teaching, and causes many effects in the learning process. The importance of understanding the educational infrastructures, is the main purpose of this study, which tries to categorize the typologies, morphology, and space distribution of schools, designed in the years 1945-1990. This period corresponds to the largest number of school's constructions of 'type models' in Albania. The study is focused on the analysis of 150 different school's plans and based mostly on primary resources collected from the Central Technical Archive of Construction, Tirana.
\end{abstract}

Keywords: Architecture, School, Typology, Morphology

\section{Introduction}

Education is always in the process of continuous reforms, while in Albania the school buildings have been designed and still remain largely in the same form. Students spend a great part of their lives inside these buildings, which teach, inform, protect, and become part of their formation. Although teaching can happen whenever and wherever, this physical environment is an important tool in the architect's hands. Schools can benefit from the architectural design and it can influence student performance, their behaviors, social impacts, and also the energy cost of the school "Although a particular learning environment does not determine the learning-and the teaching experience that is developed there, it is clearly a help or an obstacle to specific activities or uses."[3]

The study is focused on the analysis of 150 different school's plans and based mostly on primary resources collected from the Central Technical Archive of Construction in Tirana.

To understand and analyze the main typologies of educational buildings, the process should pass through the changes they have encountered during the course of history, and identify some of these influences that have shaped the educational buildings up to this day.

A short history of the schools' architecture in Albania during 1945-1990.

The period 1945-1990 is the phase when the Albanian schools got full physiognomy with the beginning of standardization and mass typologies. Also full norms and standards were created on school buildings. Even within this phase there are developments and stages of timeframes that determine other types and characteristics of school buildings. After the Second World War, in November 1944 the communist regime was established and Albania was significantly

${ }^{3}$ Woolner 2010, p.1 
underdeveloped in many areas, especially in education. A large number of villages did not have schools, while secondary schools were built only in six cities. Over $80 \%$ of the Albanian population was illiterate. Among the historical events that strongly influenced the education sector, but also the buildings were:

The decision to build schools in every corner of Albania. The foundations and basic principles of the new education system were established and they were: free, compulsory, (primary) education, unified education system (organic links between all levels of education), equal education for men and women, secular education in mother tongue, etc. [4]

A strong influence was also the idolization and desire to imitate the Soviet Union, or other socialist countries, with norms, ideas on pedagogy, construction mode, monumental architecture, etc., all of which started a grotesque, heavy and monumental architecture. "Stereotypes of archaic classicism in the architecture that prevailed in the Soviet Union were also imposed in our country." [5] In both residential and social buildings constructed in Albania, during the first 10 years and mainly in the 11-year schools, reflected an eclectic architecture with decorative and unnecessary elements in the frontal facades.

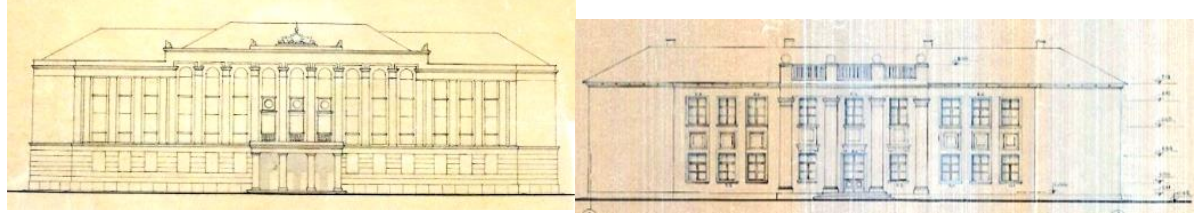

Fig. 3. Left: Variant for the Facade of the Gymnasium for Cities, Year of Project: 1953,

Architect: Valentina Pistoli. AQTN. Right: 7-year- School of two-stores, frontal. Year of Project 1954. Architect Vangjel Russi. AQTN

In 1955-1956 "A decade of wrong design was vanishing."[6] The new architecture of schools received new shapes based on the school of functionalism and European nationality. [7] The changes of the organizational structures in education that happened in 1963, transformed the 7year-compulsory system to an 8-year- compulsory and the 11-year in the 12-year system including a confrontation of architects with designs from the past, signed a milestone for some tendencies towards a more modern architecture in educational buildings. But this tendency, was eradicated and disappeared quickly under the political pressure of a unique and typical architecture, standardization and economic restrictions.

The architecture of 1963-1975 period was characterized by 'Type'- Tip ${ }^{8}$, (a unique and typical architecture), the same all over the country with derivatives of the same typology having great deficiencies in originality and creativity, constricted by the limited amount of funds and construction costs.

\footnotetext{
${ }^{4}$ Koliqi, 2002, p. 440

${ }^{5}$ Bego, 2009, p.5

${ }^{6}$ Kolevica, Architecture and Dictatorship, 2004,p. 74

${ }^{7}$ Faja, 2008, p. 15

${ }^{8}$ The State Design Institute part of the Civic Construction Design Directory was responsable for projecting prototype educational structures refered by names: Type-1, 2, etc., and the year of design.
} 

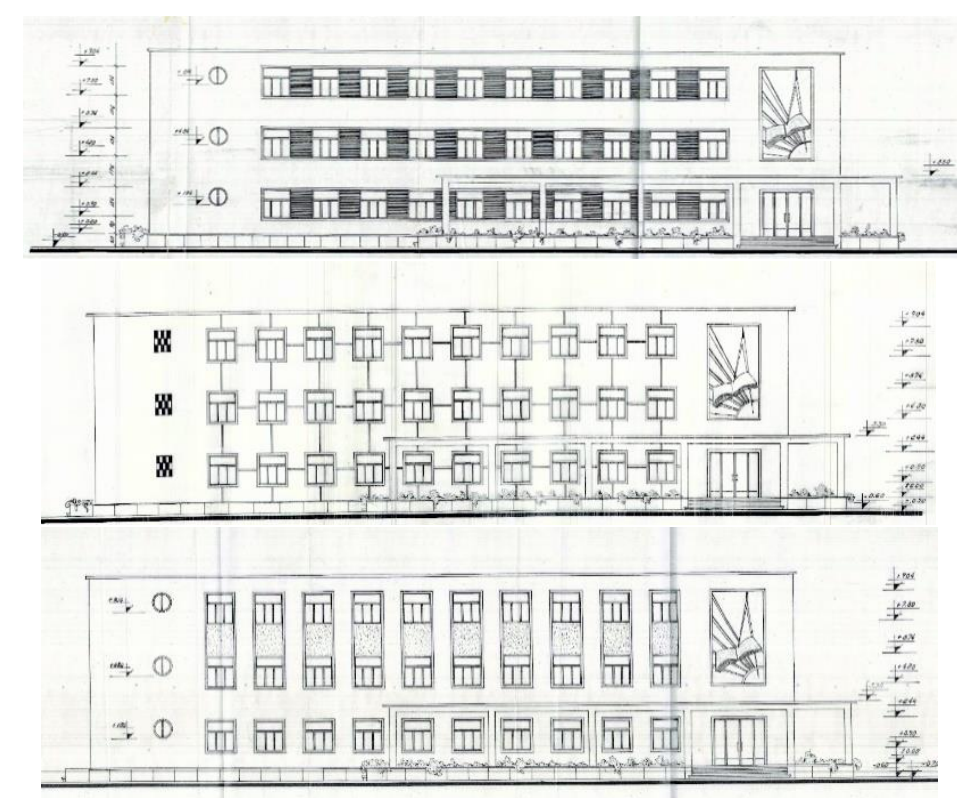

Fig. 4. Facade variations of the 7-year-old asymmetrical type school, year 1961. Arch.

Valentina Pistoli, Rexhep Faja.

"The educational system and architectural trend in general included the factory's tendency, based on the fast and low-cost construction of schools without regard to uniqueness, and adaptation to the learning process. Cultural, geographical, social, and ideological aspects were not priorities compared to the interest of creating a unified education system. Thanks to the lack of budget for school building, the interest and focus on school infrastructure, was scarce in regards to pedagogy, social organization, interior space, and other physical elements. "[9]

The slogan that inspired the country's economy and especially the construction: "Saving, saving and just saving, everywhere and anywhere, so often repeated with rampant screams" influenced also education by giving its morphology to the educational building's. [10]

In the years 1973-1974 a war against foreign influences began, and the architects frightened by this "hunt" simplified at maximum the school buildings. According to Begos, those architects who managed to reduce the cost of the preventive up to $25 \%$ less than the forecast were praised. [11]

The political and economic isolation of Albania, the difficult economic situation, along with the slogans for saving and the fight against foreign influences, led to the total clearing of the school from the architectural elements. The number of floors and classes was increased to maximize savings, windows and doors were reduced and needed to be prefabricated forcing the creation of monotonous and uniform schools throughout the country.

After designing in 1978/1979 building types for general high schools as well as for elementary schools, education was faced with a large gap in funding. Types planned to be built only for a five-year period, till 1983-1984, were used massively, because the construction cost resulted low and no new type designs were planned by the Design Institute. This enormous simplified school's design used widely began to transform the educational building resembling warehouses,

\footnotetext{
${ }^{9}$ Pasalar, 2003

${ }^{10}$ Kolevica, 2004, p. 154

${ }^{11}$ Bego, 2009, p. 29
} 
storerooms, barns, light or industry facilities, and did not show anything unique and characteristic in architecture, morphology or volume.

\section{Typologies based on morphological development}

The period of the totalitarian regime in Albania (1945-1990) corresponds to a variety of educational buildings that are illustrated by morphology and spatial patterns that generally follow traditional types with very few differences among them. "Some of these forms come as a result of the specific characteristics of the school, the level of education, and the number of students. But they also depend on climate conditions, urban or rural, and type of pedagogical philosophy." [12] Based on these important factors, a categorization of key typologies is made.

If we group schools by their structural organization there are three main categories: primary school, elementary schools and secondary schools. While if the main criteria is geographical position of the building they may be grouped in urban and rural schools. Rural school had small annexes that served as a mini-apartments for the teachers. While schools constructed in an altitude over 500 meters had a thickness of the perimeter wall $50-70 \mathrm{~cm}$ and different shape of the roof or terrace. The data shows that there is another group based on the school size, where the number of classrooms is to be considered.

Despite the fact that the Albanian school buildings do not represent a great variety regarding the morphological spatial development, they may be divided into two main groups: Frontal Schools (Symmetrical) and Non-Frontal (Asymmetric) Schools. The division is clear and carried out in the plan and also on the facade. School symmetry starts from the placement of the main lobby and of the staircase in the center of the entrance or positioned at the corner of the building.

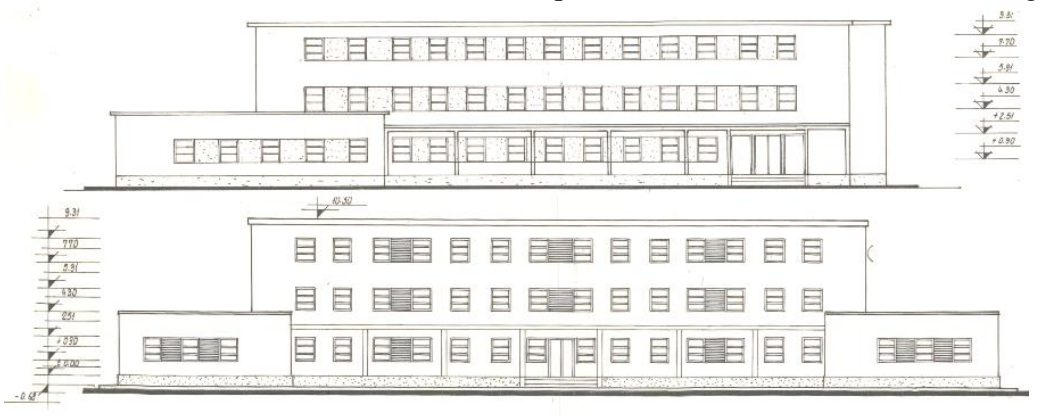

Fig. 5. Project of Facade "Type for 12 year asymmetric and symmetrical school, year 1971", Ministry of Construction, State Design Institute, Civil Engineering Design Directorate.

Architect Kostaq Sahaticiu in 1964 states: "The schools have longitudinal stretches with corridors built in the middle, the classrooms on one side and laboratories and cabinets on the other. The stairs are placed midway or at the side, defining the symmetric or asymmetric type, but in fact the volumes do not have any differences. The symmetric type can easily turn into an asymmetric type and vice versa, since each one is not inherently connected to its solution. "[13]

Defining design's typologies has as starting point, the design patterns in the education buildings, "which focus mainly on the factors that affect the area of education space as well as the areas of

\footnotetext{
${ }^{12}$ Rigolon 2010

${ }^{13}$ Central Technical Construction Archives, 2015
} 
socialization."[14] We can say that the separation between typologies about the form of space distribution are made by the organization of didactic spaces (classrooms, laboratories) with those of the distribution (corridors, holes, stairs), and the relationship that these spaces have with the outside premises of the school.

In addition to symmetrical and asymmetrical shapes according to the morphological forms, two are the most commonly used variants: the "Compact-block" variant and the "Yard" variant.

\section{Symmetrical schools}

The analysis of the design plans and data collected during the study, showed that symmetric schools are widespread in our territory and this is probably related to many reasons:

The symmetric schools have been built in in Albania for many years and as a consequence have defined a legacy rooted in the memory of architects. Since the symmetric schools have a central entrance and the hub starts at the middle of the structure, the transition to the didactic environments runs faster providing easier access. From estimates and description relationships, found in Central Technical Construction Archive, the symmetrical schools appeared a bit cheaper in construction costs, a factor that played an important role in their diffusion.

The symmetry is also displayed and emphasized by the monumental central entrance on the frontal facade.

\section{Asymmetrical schools}

The first variant of the asymmetric school was introduced in the high school type of 1961's and the elementary type of 1961, designed by the architect Valentina Pistoli, and then spread to secondary schools (1976-1979). These revised variants of 1964 were widely used in high schools, while primary and eight-year schools remained mostly symmetrical.

From the technical and economic data presented in 1974 regarding the norms of schools and the 9 typologies used in small villages or small towns, the asymmetric school has a higher construction cost, which was reflected in the tendency towards symmetrical and compact projects. ${ }^{15}$ Regardless of the slight changes in the plan, both symmetric and asymmetric schools appeared almost equally in volume and on the facade. "In essence symmetric schools differ from asymmetric schools only from the pace of the windows while volumes remain the same." [16]

\section{Compact- block variant}

The Compact block type is the most common morphology in school building. If we look at the three main units which form this school typology like the didactic classrooms, the halls and the outer spaces and the relationship they form with each other within the block unit there are two main subdivisions: the block with the central lobby and the linear block with corridors.

Block type with central lobby. The good thing about this typology is that all the lesson and service spaces are grouped around a large hall that is the heart of the school. It serves as a distribution space as also as a socialization space.

Linear - Block type. The main corridor is the spine bone of the school building. It distributes the main didactic and auxiliary environments.

\footnotetext{
${ }^{14}$ Rigolon, 2010

15 The asymmetric 2-storey school with 480 students and 12 classrooms had a cost of 480.000

ALL while symmetric schools are presented at lower cost.

${ }^{16}$ Kostaq Sahatqiu, 1964
} 
In both sub-alternatives the outer spaces wrap and protect the block. (Fig. 4)

\section{Yard variant}

The yard version has as compositional center the outer space, which according to the research has resulted in two main forms: clad or open. Their volumes usually follow a linear pattern, and form one or more floors. The choice between opened or closed outer space, thus forming a microcosm, depended heavily on location. Unlike other countries of Europe who choose to use a closed yard type in urban density areas and open courtyards in the suburbs, or in rural areas, as the landscape is an important element, in Albania the phenomenon happened differently. In rural areas, mainly in elementary schools with 12-classrooms, the closed yard type ${ }^{17}$ was used. Meanwhile, in urban areas where more "protected spaces" are required, the opened yard of L or $\mathrm{U}$ shape is mostly used. (Fig. 5)
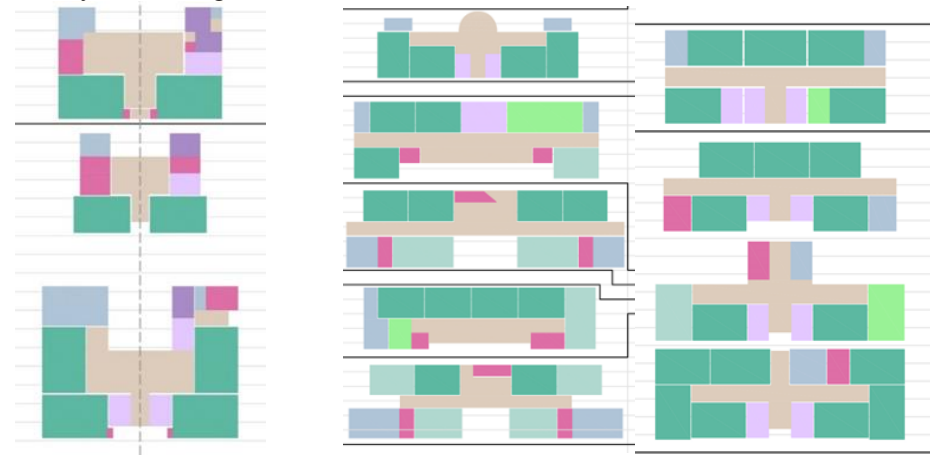

Fig. 6. Left: schemes of block typology with central lobby. Center and right: Linear block schemes of school typology.

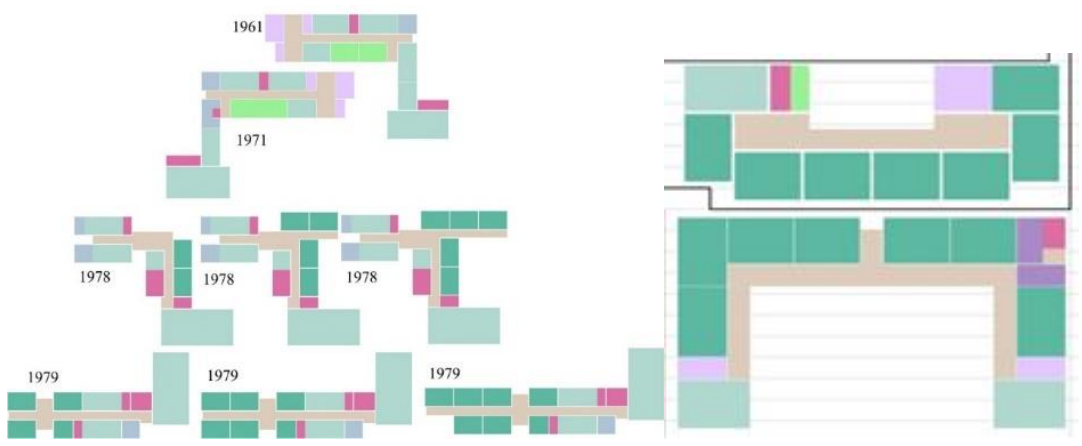

Fig. 7. Yard variants of school typology of L and U shape

\section{Conclusions}

The research attempted to identify key typologies of educational buildings in order to understand how they evolved over the course of history. In Albania, educational building projects are an

${ }^{17}$ Type 1974 
expression of economic costs and the budget became the main variable thus choosing the cheapest variant. Architects have not been able to emerge from the typologies approved by the Ministry, by adopting the official variant and trying slight changes in the façade or at the entrance. Morphological developments are scarce and the schools according to the design patterns can be divided into two main types: the Block- Compact type and the Yard Type.

The linear-block school is probably the most widespread variation of schools due to the following reasons:

-If we are concerned about the density of construction, research suggests that block typologies are more favorable in urban areas due to their compact footprint. Perhaps, a reason for using this typology massively is because they can be placed in spaces not very favorable, close to existing infrastructures and have a discrete and simple style.

-The optimum of net useful area (didactic surface in square meters relative to the total area in square meters) is an essential estimate given the tight budget for the school buildings. Block type variants are always cheaper in terms of cost, since in the linear block variants, the corridor space saves a lot of space per square meter as it functions for distribution, recreation, gathering, etc., as a space with multiple functions rather than just crossing.

-Regarding the level of education, the block type school is more favorable as our curricula developed mainly in classrooms, and less in labs and other school environments, outdoors or open spaces. Since the students had only 5 minutes available from one subject to the next, another scheme would be inappropriate for distributing students from one environment to another as it would take longer and it may be problematic.

In conclusion slight fluctuations in the design, the facade and volume remained problematic in this period characterized by simplicity, lack of details, and the poverty of architectural materials and architectural elements.

\section{References}

1. Bego, M.: Skeda Arkitekture 1965-2004 në kronikën e një jete të dallgëzuar. Monografi, çështja e Strehimit në periudhën e Realizmit Socialist. Tiranë: DEA, Sh.P.K. (2009)

2. Central Technical Construction Archives: "Fletë Projektesh, shkollash."-Shënime Teknike. (2015)

3. Faja, E.: Kush e drejton urbanistikën Shqiptare? Përmbledhje artikujsh kritikë 1991-2008. Tirana: UFO Press. (2008)

4. Kolevica, P.: "Një vështrim kritik ndërtimeve tona." Zëri i Popullit, January 28. (1966)

5. Kolevica, P.: Arkitektura dhe diktatura. Tirana: Logoreci. (2004)

6. Koliqi, H.: Historia e arsimit dhe e mendimit pedagogjik Shqiptar. Pristina: University of Pristina: Philosophic Faculty, Scholar Library (2002)

7. Pasalar, C.: The Effects of Spatial Layouts on Students' Interactions in Middle Schools: Multiple Case Analysis: North Carolina: Faculty of North Carolina State University (2003).

8. Rigolon, A.:"European design types for 21st century schools: an overview." www.oecd.org/publishing. 03. (2010) Accessed 04 22, 2016.

9. Sahatçiu, K.: "Recension për projektin Tip të Shkollave 8-vjeçare." Shkresa mbi Projektin Tip. Tirana: Vendimi Nr. 93 i Këshillit Teknik të Ministrisë së Ndërtimit, (3 November 1964)

10. Woolner, P.: The design of learning spaces. New York: Continuum International Publishing Group (2010). 